\title{
COMPARATIVE STUDY OF HYPABYSSAL KIMBERLITE FROM FOUR LOCATIONS WITHIN THE SLAVE CRATON
}

\author{
Jim Crawford and Herb Helmstaedt \\ Department of Geological Sciences and Geological Engineering \\ Queen's University, Kingston, Canada
}

\section{INTRODUCTION}

Kimberlites occurring within the Archean Slave craton appear to differ from the "classic" southern African model in a number of aspects. The Cretaceous and early Tertiary kimberlites of the Lac de Gras area (Fig. 1), are generally small steep-sided pipes infilled with volcaniclastic kimberlite (VK), however a few are composed of mainly hypabyssal kimberlite (HK). Both HK and VK have been found exposed at surface. The most notable feature of these pipes is the lack of tuffisitic kimberlite (TK) and/or tuffisitic kimberlite breccia (TKB), which shows that they are different from the majority of pipes in southern Africa (Field and Scott Smith, 1998). The pre-Cretaceous kimberlites occurring both north and south of the Lac de Gras area (Fig. 1), contain common TK and/or TKB, as well as HK (Field and Scott Smith, 1998). The lack of TK and/or TKB, as well as, the disparity in pipe size, indicate that the welltested southern African kimberlite model and postulates concerning near-surface emplacement, which are applicable in many parts of the world, do not adequately explain the contrasting types of kimberlites present within the Slave craton.

This study, which represents one of the first detailed comparative investigations of hypabyssal kimberlites from the Slave craton, presents petrographic, mineral chemical and whole rock geochemical data from hypabyssal kimberlite from the Finlay, Muskox, Rich and Jean bodies (Fig. 1). The four bodies are compared and contrasted with each other to illustrate some of the prominent characteristics of the different kimberlite fields present within the Slave craton. The results are then compared with data from other world-wide hypabyssal kimberlites, most notably those from the Kimberley, South Africa area. The results of this comparison provide additional lines of evidence to further evaluate the applicability of the Southern African kimberlite emplacement model to the Slave.

\section{PETROGRAPHY}

Although the amount of kimberlite available for examination was quite limited, it was sufficient to illustrate some of the unique characteristics of each body, as well as illustrating some of the complex inter-sample variability that is characteristic of hypabyssal kimberlite.

The samples from the Finlay body are representative of a single intrusive phase, which can be classified as a uniform textured, macrocrystic, phlogopiterich, calcite monticellite serpentine hypabyssal kimberlite.

The Muskox samples are representative of two intrusive phases; one can be classified as a uniform textured, macrocrystic, spinel-rich, monticellite serpentine calcite hypabyssal kimberlite, while the other can be classified as a uniform textured, macrocrystic, spinel-rich, serpentine hypabyssal kimberlite breccia.

The Rich samples are representative of two intrusive phases; one can be classified as a uniform textured, macrocrystic, spinel-rich carbonatized hypabyssal kimberlite breccia, while the other is a flowbanded, aphanitic, spinel-rich carbonatized hypabyssal kimberlite.

The samples from the Jean body are representative of at least four intrusive phases: a uniform textured, macrocrystic, serpentinized spinel-rich hypabyssal kimberlite microbreccia; a uniform textured, sparsely macrocrystic, serpentinized opaque oxide-rich hypabyssal kimberlite microbreccia; a flow-banded, macrocrystic spinel-rich carbonatized and serpentinized hypabyssal kimberlite microbreccia; and a sparsely macrocrystic, spinel-rich serpentinized hypabyssal kimberlite breccia.

The Finlay samples stand out due to the presence of modally significant concentrations of primary groundmass phlogopite (6.2 modal \%). Interestingly, the Finlay samples were also the only ones where no macrocrystic phlogopite was identified. This appears to be a characteristic common to the hypabyssal kimberlite occurring within the Hardy Lake claim block (McKinlay et al., 1998; McKinlay et al., 1997). This is in contrast to the majority of the Lac de Gras hypabyssal kimberlite, which is reported to commonly contain macrocrystic phlogopite (Pell, 1997).

The Muskox samples are petrographically unique among the bodies examined for a number of reasons, such as the presence of bright green chrome diopside macrocrysts, the presence of primary calcite and the presence of relatively coarse, unaltered fragments of carbonate country rocks.

The Finlay and Muskox samples represent archetypical examples of fresh Group 1 hypabyssal 


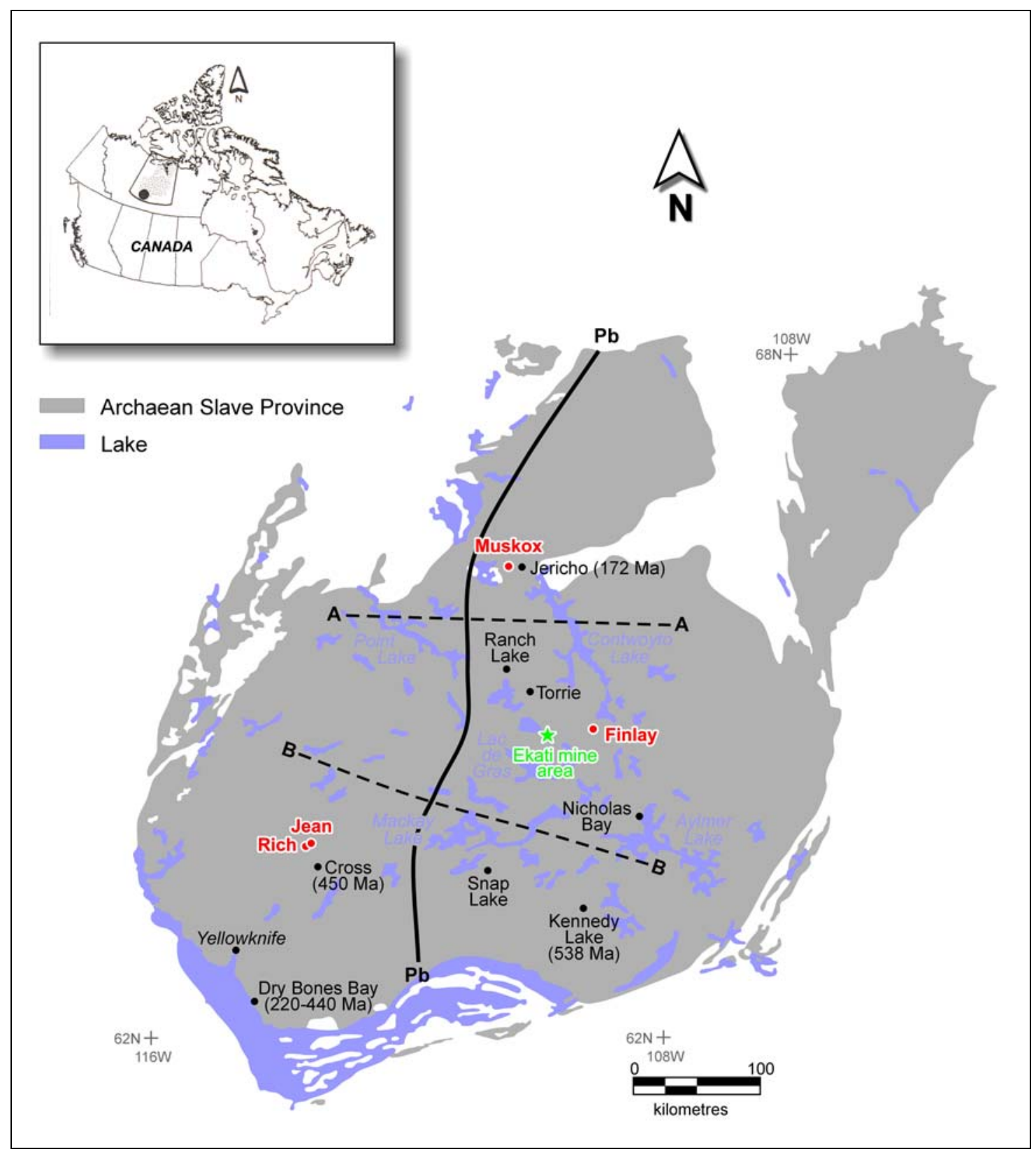

Figure 1 Location of Kimberlites examined during this study.

Line A-A is an inferred boundary between the northern Jurassic age kimberlite field and the central Cretaceous - Tertiary kimberlite field.

Line B-B is an inferred boundary between the central Cretaceous-Tertiary kimberlite field and the southern OrdovicianCambrian kimberlite field. 
kimberlite and kimberlite breccia. The low degree of alteration within these samples clearly distinguishes them from the samples of Rich and Jean. Within the Finlay and Muskox samples, the olivine macrocrysts display very minor serpentine development along grain margins and fractures. The primary groundmass phases display slightly more advanced degrees of serpentinization, however examples of fresh microphenocrystal olivine and monticellite are relatively common. In contrast, the Rich and Jean samples display almost complete serpentinization \pm carbonatization.

This disparity in degree of alteration appears to be consistent throughout the different kimberlite fields present within the Slave craton. The centrally located Cretaceous to Tertiary kimberlites and the northern Jurassic kimberlites appear to have experienced minimal alteration, whereas the southern and southwestern Ordovician to Cambrian kimberlites exhibit much more extensive alteration (Field and Scott Smith, 1998; McKinlay et al., 1998; Pell, 1997; Price et al., 2000). It is suggested that these differing degrees of alteration are a consequence of the geographic location of the craton at the time of inferred kimberlite emplacement.

Although the petrographic similarities between northern Canadian and southern African hypabyssal kimberlite are numerous, one of the characteristics that distinguishes them is their differing abundance of country rock xenoliths $<4 \mathrm{~mm}$ in longest dimension. The abundance of country rock xenoliths $<4 \mathrm{~mm}$ has led to the introduction of the term "microbreccia" in the revised classification scheme of Field and Scott Smith (1998). Although this term has not gained wide acceptance, it is clearly applicable to the Jean samples and conveys useful information that may otherwise be overlooked. This petrographic difference is more likely an indication of the differing mechanical properties of the country rocks rather than a difference in the nature of the underlying kimberlite magmas; the northern Canadian kimberlites having been emplaced through competent felsic plutonic rocks, whereas the southern African kimberlites were emplaced through rocks with highly variable degrees of competence including volcanic and sedimentary units, as well as crystalline basement.

Implicit in the preceding discussion pertaining to the classification of the Finlay, Muskox, Rich and Jean samples as Group 1 hypabyssal kimberlites and kimberlite breccias to microbreccias, is their petrographic similarity to the southern African examples of these rock types. As the petrographic characteristics of an unaltered igneous rock are a direct reflection of the physiochemical conditions within the parent magma at the time the rock was formed, the petrographic similarities between the northern Canadian and southern African hypabyssal kimberlites must reflect an underlying similarity in the parental kimberlite magmas that generated these rocks.

\section{MINERAL CHEMISTRY}

\section{OLIVINE}

The minimal alteration present within the Finlay and Muskox samples afforded the opportunity to collect mineral chemistry data from primary groundmass olivines. The olivine centers within both bodies display a compositional range from $\mathrm{Fo}_{87}$ to $\mathrm{Fo}_{93.5}$. This range is similar to that recorded from the De Beer pipe (R.S.A.), the Dutoitspan pipe (R.S.A.), the Benfontein sill complex (R.S.A.), as well as the Ison Creek (U.S.A.) and Elwin Bay occurrences (CDN) (Clement 1982, and references therein) and is considered typical of Group 1 kimberlites (Scott Smith, 1996). Edge compositions displayed a narrower range than the centers, with the Finlay samples converging to $\mathrm{Fo}_{91.5}$ and the Muskox samples converging to Fo90-90.5. Worldwide, olivine edge compositions tend to converge to approximately $\mathrm{Fo}_{91}$ (Scott Smith, 1996). Compositional zoning of individual phenocrysts displayed both normal and reverse trends, with a maximum compositional change of $3.4 \mathrm{~mol} \%$ Fo being recorded. This is consistent with compositional zoning data acquired from kimberlitic olivines throughout the world (Mitchell, 1986; Clement, 1982).

\section{SPINEL}

The spinel mineral chemistry data support the interpretation of the four bodies as representative of Group 1 kimberlites, as well as supporting the single- and multi-phase classifications that were determined petrographically.

A compositional trend, termed either the FETIE (Fe-Ti enrichment) trend (Armstrong, 1995; this study) or magmatic trend 1 (Mitchell, 1986), interpreted to be characteristic of kimberlitic spinels, is the evolution from magnesian chromites toward members of the magnesian ulvöspinel-ulvöspinel-magnetite series. As illustrated on an $\mathrm{Fe}^{3+} /\left(\mathrm{Fe}^{3+}+\mathrm{Cr}+\mathrm{Al}\right)$ versus $\mathrm{Fe}^{2+} /\left(\mathrm{Fe}^{2+}+\mathrm{Mg}\right)$ diagram (Fig. 2), the spinels from each of the four bodies under examination display variations within this general trend.

The Finlay, Muskox and Rich spinels illustrate differentiation trends of relatively unevolved parental magmas with slightly different compositions. The Finlay spinels display very limited compositional zonation, while the Muskox and Rich spinels evolve toward magnetite, indicating more extensive magmatic differentiation within their respective kimberlites. The Jean spinels display only the more evolved magnesian ulvöspinel-ulvöspinelmagnetite trend, with no evidence of a more primitive, unevolved component.

Another compositional trend believed to be common among kimberlitic spinels is, the CRE (Crenrichment) trend, which was first identified by Armstrong (1995) in microphenocrystic spinels from the C-14 kimberlite, near Kirkland Lake, Ontario, Canada. 


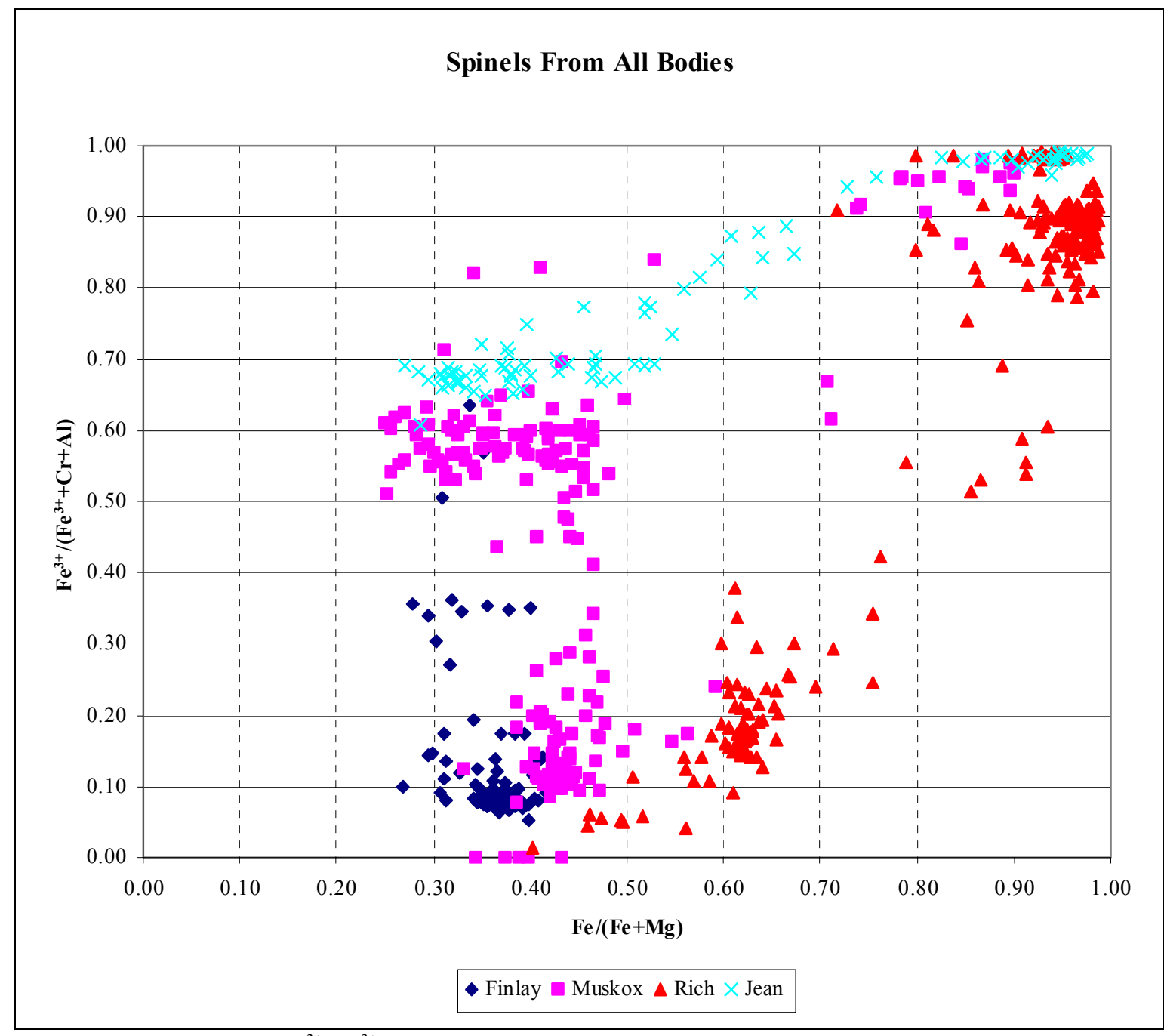

Figure 2 Plot of $\mathrm{Fe}^{3+} /\left(\mathrm{Fe}^{3+}+\mathrm{Cr}+\mathrm{Al}\right)$ vs. $\mathrm{Fe} /(\mathrm{Fe}+\mathrm{Mg})$ for Spinels from All Four Bodies

Table 1: Summary of Whole-Rock Geochemical Results From All Four Bodies

\begin{tabular}{|c||c|c|c|c|}
\cline { 2 - 5 } \multicolumn{1}{c||}{} & Finlay & Muskox & Rich & Jean \\
\hline $\mathrm{SiO}_{2}$ & $35-36.1$ & $27.5-32.9$ & $21.2-29.5$ & $25.5-35.4$ \\
\hline $\mathrm{MgO}$ & $35.5-37.6$ & $29.4-34.2$ & $24.7-29.1$ & $23.3-32.5$ \\
\hline $\mathrm{Al}_{2} \mathrm{O}_{3}$ & $1.91-2.02$ & $2.35-2.88$ & $1.85-3.4$ & $2.75-4.52$ \\
\hline $\mathrm{Na}_{2} \mathrm{O}$ & $.01-.04$ & $.05-.34$ & $.01-.25$ & $<.01-.13$ \\
\hline $\mathrm{Na}_{2} \mathrm{O} / \mathrm{K}_{\mathbf{2}} \mathrm{O}$ & $.01-.04$ & $.09-.36$ & $.02-.19$ & $<.05-.19$ \\
\hline $\mathrm{La} / \mathrm{Yb}$ & $525-600$ & $171-286$ & $219-358$ & $141-248$ \\
\hline $\mathbf{C O}$ & $2.3-3.4$ & $3.04-9.32$ & $12.1-17.8$ & $.67-8.44$ \\
\hline $\mathrm{H}_{\mathbf{2}} \mathbf{O}^{+}$ & $4.5-5.1$ & $5.5-7.5$ & $6.5-7.6$ & $7.1-12$ \\
\hline L.O.I. & $6.7-8.55$ & $10.6-15.1$ & $18.7-24.9$ & $12.2-18.2$ \\
\hline C. I. & $0.96-0.99$ & $0.94-1.04$ & $0.76-1.20$ & $0.96-1.35$ \\
\hline
\end{tabular}


The trend was identified in the earliest chromites and involves increasing $\mathrm{Cr}$ and decreasing $\mathrm{Al}$, at essentially constant $\mathrm{Fe}^{3+}$ and Ti. (Armstrong, 1995). Armstrong (op. cit.) tentatively identified the trend within published data from the Koidu, Cross, Wesselton and De Beers kimberlites, as well as the 6 Mile Creek and Reservoir kimberlite dykes, although he acknowledges that the identification was hampered as a result of sparse data.

The CRE trend is well developed in the Finlay and Rich spinels and poorly developed in the Muskox spinels. It was not detected in the Jean spinels as a result of very low chromium concentrations ( $\mathrm{Max} . \mathrm{Cr}_{2} \mathrm{O}_{3}=3.37$ wt. $\%$; $\mathrm{Cr}$ (cations) $=0.09$ ). Its predominance in the generally unevolved Finlay spinels and its restriction to a small subset of the Rich center compositions support Armstrong's (1995) suggestion that the CRE trend is confined to the earliest forming chromites. This study represents the first documented occurrence of the CRE trend within Slave craton kimberlitic spinels, and its occurrence in the youngest, as well as one of the oldest kimberlites examined supports Armstrong's (1995) postulate that the CRE trend is common in kimberlite groundmass spinels.

\section{GEOCHEMISTRY}

The whole rock geochemical data are consistent with the petrographic and mineral chemistry data, indicating that the samples examined during this study are typical examples of Group 1 hypabyssal kimberlites. The data presented in Table 1 clearly illustrate the undersaturated, ultramafic, potassic, volatile-rich character of the samples. The ranges in volatile content $\left(\mathrm{H}_{2} \mathrm{O}\right.$ and $\left.\mathrm{CO}_{2}\right)$ recorded for these Slave craton kimberlites are very similar to the ranges recorded for these elements from Kaapvaal craton kimberlites. The contamination index (C.I.) (Clement, 1982) values around unity for the majority of the samples are indicative of their relatively fresh, unaltered nature. This is consistent with their significant LREE enrichment, relative to their HREE content, which is another geochemical characteristic displayed by kimberlites.

\section{CONCLUSION}

Although there is considerable variation between the different kimberlites examined, the results of this study reveal that all four locations, regardless of pipe age, contain typical Group 1 hypabyssal kimberlite and/or kimberlite breccia to microbreccia. The results also show that, for the parameters investigated, hypabyssal kimberlites from the Slave craton are similar to those from other cratons throughout the world. This suggests that the contrasting nature of the kimberlite pipes within the Slave craton, relative to the "classic" pipes of southern Africa, does not result from variations in the nature of the erupting magma. The differences more likely reflect parameters unrelated to the kimberlite magmas, such as contrasting country rock geology and the surface environments of emplacement, as suggested by Field and Scott Smith (1998).

\section{REFERENCES}

Armstrong, K.A., 1995. An Investigation of the Spinel Mineralogy of the C14 Kimberlite, Kirkland Lake, Ontario. MSc. Thesis, Queen's University, Kingston, Ontario, $150 \mathrm{pp}$.

Clement, C.R., 1982. A comparative geological study of some major kimberlite pipes in the northern Cape and Orange Free State. Ph.D. Thesis, University of Cape Town, Cape Town, S.A.

Field, M. and Scott Smith, B.H., 1998. Contrasting geology and near-surface emplacement of kimberlite pipes in Southern Africa and Canada. In: J.J. Gurney, J.L. Gurney, M.D. Pascoe and S.H. Richardson (Editors), Proceedings of the VIIth International Kimberlite Conference, Cape Town, pp. 214-237.

McKinlay, F.T., Scott Smith, B.H., de Gasparis, S. and Kong, J., 1998. Geology of the Recently Discovered Hardy Lake Kimberlites, NWT. In: J.J. Gurney (Editor), VIIth International Kimberlite Conference, Cape Town, South Africa, pp. 564-566.

McKinlay, F.T., Williams, A.C., Kong, J. and Scott Smith, B.H., 1997. An Integrated Exploration Case History for Diamonds, Hardy Lake Project, NWT. In: A.G. Gubins (Editor), Exploration '97: Fourth Decennial International Conference on Mineral Exploration, pp. 1029-1038.

Mitchell, R.H., 1986. Kimberlites: Mineralogy, Geochemistry and Petrology. Plenum Press, New York, 442 pp.

Pell, J.A., 1997. Kimberlites in the Slave Craton, Northwest Territories, Canada. Geoscience Canada, 24(2): 77-90.

Price, S.E., Russel, J.K. and Kopylova, M.G., 2000. Primitive Magma From the Jericho Pipe, N.W.T., Canada: Constraints on Primary Kimberlite Melt Chemistry. Journal of Petrology, 41(6): 789-808.

Scott Smith, B.H., 1996. Kimberlites. Mineralogical Association of Canada, Short Course Series, 24: 217-243.

Contact: J Crawford, 602-1441 St. Georges Ave, North

Vancouver, BC, Canada, V7L 3J4,

E-mail:jcrawf@attcanada.ca 